\title{
加硫ゴムの伸長変形下におけるネットワーク構造変化
}

\author{
伊 藤 眞 義
}

\section{Changes in the Network Structure of Vulcanizates During Tensile Deformation}

Masayoshi ITO(Graduate School of Chemical Sciences and Technology, Tokyo University of Science, 1-3 Kagurazaka, Shinjuku-ku, Tokyo 162-8601, Japan) itma56@rs.kagu.tus.ac.jp

Electron spin resonance (ESR) is a powerful technique to study the mechanochemical reactions in deformed polymeric materials including elastomers.

This review gives results of ESR measurements of vulcanizates under tensile deformation. The measurements were carried out by the combination of home-built stretching machine with commercially available ESR spectrometer. The destruction and re-combination of crosslinking structure developed in the vulcanizates were confirmed by the changes of radical concentration during tensile deformation. Further, the degree of strain induced crystallization in vulcaniates was correlated with the partial breakdown of network structure in the vulcanizates.

Key Words : ESR, Tensile Deformation, Radical Concentration, Breakdown of Crosslink Structure, Strain Induced Crystallization

\section{1. 緒言}

ゴム材料は，その特性上大変形下で使用される場合が多 い. 大変形を受けたゴム材料中の高分子鎖および架橋構造 体にはひずみによる大きな力が作用するため，分子鎖切断 や架橋構造破壊が起こり，その結果各種ラジカルが発生す る可能性がある.これらのラジカル種がゴム材料中で化学 反応を引き起こすと, ゴム材料の構造や物性が変化するこ とになるゆえ, 変形下で発生したラジカル種の定量的解析 は重要である.

Natarajan らは1), 加硫促進剤としてN-cyclohexylbenzothiazole sulfenamide（CBS）を用いて硫黄架橋した 天然ゴムに伸長変形を加えた後ひずみ回復を行った試料に ついて電子スピン共鳴（ESR）測定を行いラジカルの存在 を確認した.Meadらも2), ポリイソプレンやポリブタジ エン過酸化物架橋試料に伸長変形を加えた場合炭素ラジカ ルが発生することを見出している，筆者らは ${ }^{3,4)}$ ，シリカ 充てんスチレンブタジエンゴム (SBR) 加硫試料について, ひずみ印加による化学結合切断の可能性を検討した，その 結果, 充てん系ゴム材料でも変形によるラジカル発生が認 められるとともに, その程度は硫黄架橋試料で特に顕著で あることを報告した。これらの報告にもとづくと，ゴム材 料中に存在する化学結合の一部が変形を受けることにより 破断することは明らかである。
化学結合切断によって発生したラジカル種の寿命は種々 の要因に支配されるが, 室温においてゴム材料中に発生し たラジカルの寿命は一般に短いため ${ }^{5)}$, 上記研究における ESR 測定は, 室温で伸長変形後ただちにー $100^{\circ} \mathrm{C}$ 程度まで 冷却してライフタイムを長くした上で行っている.この場 合, 発生したラジカルの凍結状態に扔ける定量的解析はあ る程度可能ではあるものの, 発生直後からの挙動, 特に伸 長変形下での挙動を定量的に扱うことはできない.

筆者らは, この問題を解決する方法として, 市販の ESR 測定装置に自作の一軸伸長延伸機を取り付け，伸長 変形下に扔ける ESR 測定を試みた ${ }^{6)}$. 本稿では, 装置およ び測定法の概略を説明した上で, 得られたデータのいくつ かを紹介する。

\section{2. 装置と測定法 ${ }^{6)}$}

\section{1 一軸伸長延伸機の ESRスペクトロメータへの組み} 込み

実験に用いたESRスペクトロメータは，JEOL 製JES-

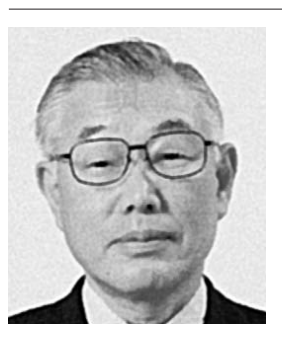

伊藤眞義: 東京理科大学大学院総合化学研究科 嘱託教授, 理学博士（１62-8601 東京都新宿区 神楽坂 1-3). 昭和 45 年 東京理科大学大学院理 学研究科修士課程修了, 昭和 47 年 東京理科大 学理学部助手. 専門は高分子材料物性. 日本ゴ 么協会関東支部長. 
FA200である.これのキャビティ部に延伸機を取り付け ることで一軸伸長下でのESR 測定を可能にした. Figure 1 はその概略図を示したものである。試料を挟み込むクラン プをキャビティ外部に設置する必要があることから試料の 最小長はキャビティのサイズに依存する，本実験ではクラ ンプ部も含めた最小試料長は $110 \mathrm{~mm}$ であった。また，ク ランプ間最大移動距離は，マグネットの形状による制限か ら本実験では500 mmであった。なお，両クランプとも独 立した移動機構を有しており，延伸軸に対して上下同じ速 度で延伸することによりキャビティ内の変形がなるべく均 一になるようにした。

クランプは，磁場への影響を考慮して非磁性体の金属と セラミックを併用し，最大約 $20 \mathrm{~N}$ の荷重に耐える構造に した。キャビティ内の温度は，温度制御された窒素ガスを 導入することで設定温度に対して $\pm 0.5{ }^{\circ} \mathrm{C}$ 以内にて制御可 能であった。

\section{2 測定方法とデータ補正}

キャビティ内の試料形状と体積は伸長変形に伴い変化す る。これらの変化のもとで SN比が良好，かつひずみの少 ないスペクトルを得るための条件と, 得られたスペクトル の補正について SBR 試料を用いて検討した。

伸長変形中はESR スペクトロメータの安定度が低下し， 良好なスペクトルを得ることが困難であった。そこで測定 は引張り速度をゼロとして行った。したがって，測定は 一定ひずみのもとで行うことになり測定中に応力変化が生 じた。この変化による $\mathrm{g}$ 值の変動は認められなかったが, ラジカル濃度はこの影響を受ける可能性がある。それゆえ この影響をなるべく小さくするために測定を短時間で行う 必要があった。そこで，ひずみ $10 \%$ 毎に引張り速度をゼロ として測定を行う場合の磁場掃引時間と積算回数の最適化 を検討した。その結果，最低磁場掃引幅は7.5 mTであり， その掃引時間は約 20 秒であること, 積算回数は最低 2 回必 要であることから，あるひずみにおける測定必要時間は約 40 秒であることがわかった。この時間内におけるラジカ ル濃度の変化はそのライフタイムを考慮した場合無視でき ない可能性がある ${ }^{5)}$ 。しかし，これは磁場掃引法による測

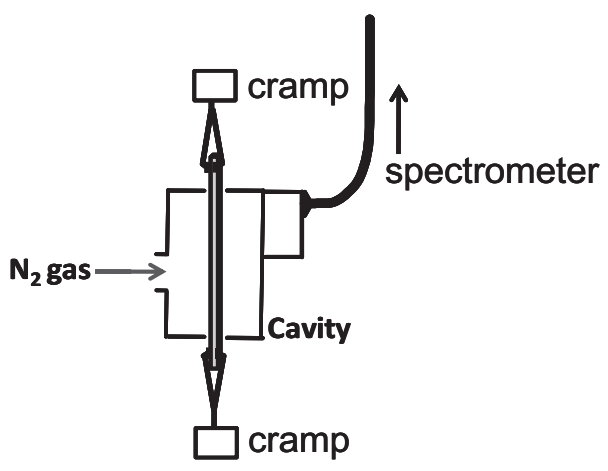

Figure 1 Schematic image of ESR cavity with drawing machine
定では避けられない問題であり，適切な対処法も見当たら ないことから，これに対するラジカル濃度の補正は行わな かった。

ラジカルの検出感度は，キャビティ内の試料位置に依存 する。そこで，ラジカル検出感度と試料形状および位置の 関係を検討した，用いた試料は厚さ $1 \mathrm{~mm}$ の加硫シートで ある。このシートには作製時に発生した比較的長いライフ 夕イムを有するラジカルが含まれており，検出感度の検討 を行っている間のラジカル濃度変化は無視できる. 長さ $20 \mathrm{~mm}$, 幅 $2 \mathrm{~mm}$, 厚さ $1 \mathrm{~mm}$ の試料を用いて検討を行 った，静磁場内におけるキャビティの位置と，静磁場に対 して垂直方向の試料設置軸の設定を行った後，試料設置軸 上で試料を移動させラジカル検出感度最大となる位置を決 定し，この点を試料設置軸のゼロ点とした。 ゼロ点を中心 として設置軸上で試料を移動し，それぞれの点におけるラ ジカル数の測定を行った。ラジカル濃度は, 外部標準とし て 4-hydoxy-2,2,6,6-tetramethylpiperidine-1-oxyl radical （TEMPOL）水溶液を使用し，その吸収スペクトル積分值 から算出した。次に試料設置軸のゼロ点を中心として軸方 向に試料長をかえて，ラジカル数と試料長の関係を調べ, その結果をFigure 2 に示した. ラジカル検出感度最大位 置から試料設置軸上下方向にそれぞれ $20 \mathrm{~mm}$ ずつまでは 試料長の増加にともない信号強度が増大するものの，その 後試料長の増加にともなう信号強度の増加は認められなか った。これらの結果から, 伸長変形に伴う体積変化に対す る信号強度補正は，キャビティ内の検出感度最大位置を中 心として上下それぞれ $20 \mathrm{~mm}$ 部分について行えばよいと 判断した。なお信号強度補正は，信号強度が上述の 40 $\mathrm{mm}$ における試料体積とほぼ比例関係にあることを利用し て行った.

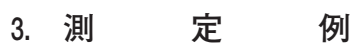

3.1 伸長変形下における ESRスペクトル SBR 用いて過酸化物架橋 $(\mathrm{SBR} / \mathrm{DCP})$ と二種類の硫

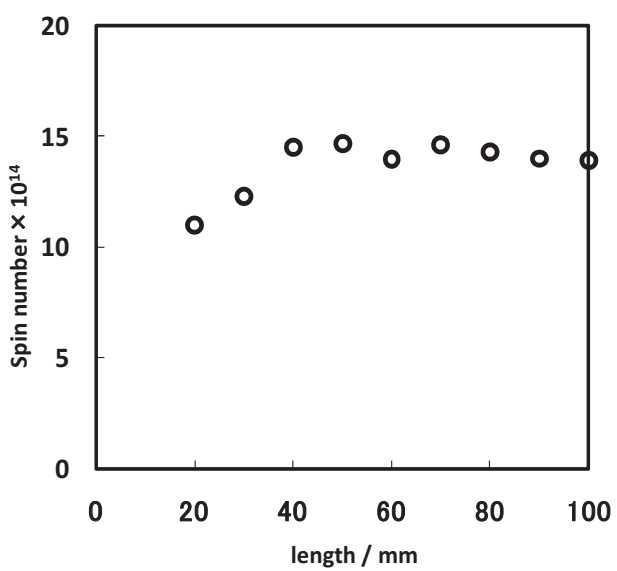

Figure 2 Relation between sample length in the cavity and number of spins 
黄架橋（SBR/Sulfur/CBS，SBR/Sulfur/TMTD）試料を 作製し， $-20{ }^{\circ} \mathrm{C}$ での伸長変形による $\mathrm{ESR}$ スペクトル変化 を観察した。Figures 3〜 5 は，それぞれSBR/DCP， SBR/Sulfur/CBSおよびSBR/Sulfur/TMTDの結果を示し たものである。なお，試料は，Table 1 に示した配合表に より作製したものであり，スペクトルは伸長による体積変 化に対する補正を行ったものである.

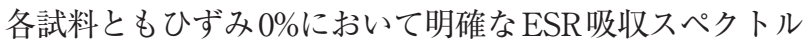
を示した。これは, 試料作製時の混練や架橋操作で発生した ラジカルによるものである. SBR/DCP試料（Figure 3）はひ ずみ $0 \%$ から破断にいたるまで $\mathrm{g}$ 值として 2.004 を有する単一 吸収を示し，その強度はひずみ増加とともに増加するものの， スペクトル形状には変化が認められなかった. SBR/DCP試 料中に発生するラジカル種は炭素－炭素結合の切断で発生す る $\mathrm{g}$ 值として 2.004 を有するポリエニルラジカルであることを 考慮すると ${ }^{2)}$, 伸長変形にともなうスペクトル強度の増加は, ゴム分子鎖を含むネットワーク構造の一部が伸長変形により 破壊されることを示している.

SBR/Sulfur/CBS 試料（Figure 4）も定性的には $\mathrm{SBR} / \mathrm{DCP}$ 試料と同様， $\mathrm{g}$ 值として 2.004 を有する単一の吸 収スペクトルを示す。この試料では主として炭素－炭素結 合，炭素一硫黄結合および硫黄一硫黄結合によりネットワ

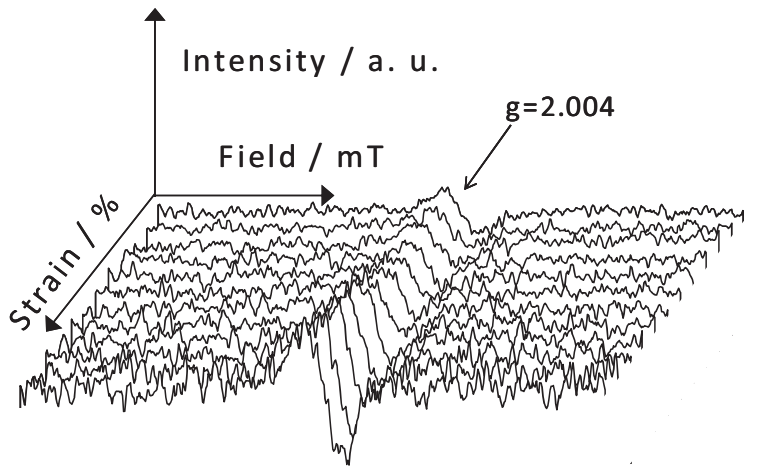

Figure 3 ESR spectra for SBR/DCP at $-20{ }^{\circ} \mathrm{C}$
ーク構造が構築されている。これらの中で結合エネルギー の最も小さい結合は硫黄一硫黄結合であること, 硫黄ラジ カルの中には $\mathrm{g}$ 值として 2.004 を有するラジカル種がある ことから, Figure 4で認められた吸収はポリエニルラジカ ルと硫黄ラジカルによるものと考えられる ${ }^{5)}$ 。これらのラ ジカル濃度も伸長変形増大に伴い増加した。

Figure 5 はSBR/Sulfur/TMTD 試料について，伸長変 形にともなう ESR スペクトルの変化を示したものである. スペクトルは, Figure 3 および 4 に示したそれらとは異な り， $\mathrm{g}$ 值として $2.014 ， 2.004$ および 1.978 を有する三成分の

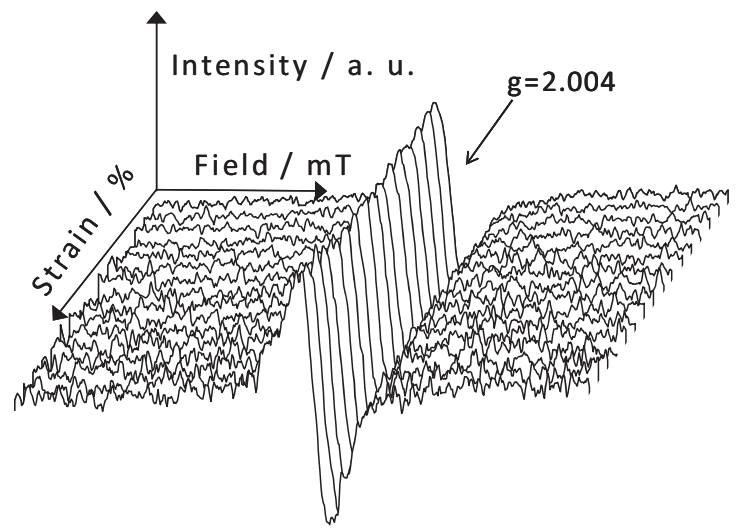

Figure 4 ESR spectra for SBR/Sulfur/CBS at $-20{ }^{\circ} \mathrm{C}$

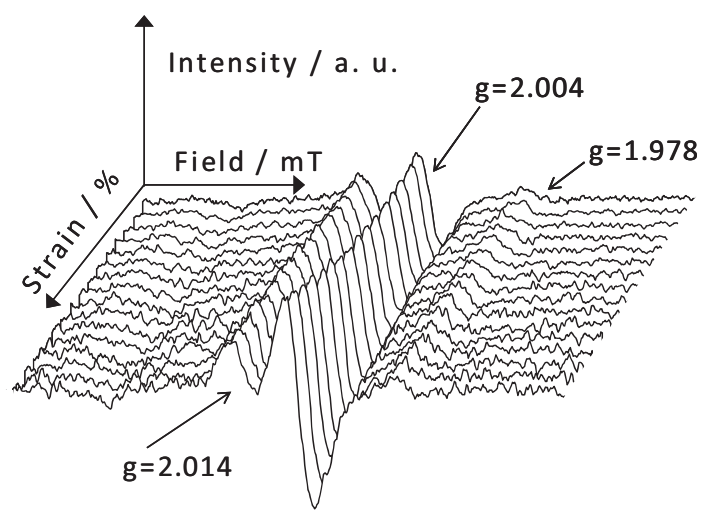

Figure 5 ESR spectra for SBR/Sulfur/TMTD at $-20^{\circ} \mathrm{C}$

Table 1 Formulation of the compounds and crosslink densities

\begin{tabular}{|c|c|c|c|c|c|}
\hline \multirow{2}{*}{ Ingredient } & \multicolumn{5}{|c|}{$\mathrm{phr}^{\mathrm{a})}$} \\
\hline & $\mathrm{SBR} / \mathrm{DCP}$ & SBR/Sulfur/CBS & SBR/Sulfur/TMTD & $\mathrm{PD}$ & PS \\
\hline $\mathrm{SBR}^{\mathrm{b})}$ & 100 & 100 & 100 & - & - \\
\hline $\mathrm{IR}^{\mathrm{c})}$ & - & - & - & 100 & 100 \\
\hline Zinc oxide & - & 3 & 3 & - & 3 \\
\hline Stearic acid & - & 2 & 2 & - & 2 \\
\hline $\mathrm{DCP}^{\mathrm{d})}$ & 0.5 & - & - & 2 & - \\
\hline Sulfur & - & 3 & 3 & - & 1.5 \\
\hline $\mathrm{CBS}^{\mathrm{e})}$ & - & 0.6 & - & - & 1.5 \\
\hline TMTD $^{\mathrm{f})}$ & - & - & 0.3 & - & - \\
\hline$v \mathrm{e} \times 10^{-4} / \mathrm{mol} \cdot \mathrm{cm}^{-3}$ & - & - & - & 1.56 & 1.46 \\
\hline
\end{tabular}

a) weight per hundred rubber, b) styrene-butadiene rubber, c) 1,4-cis-polyisoprene,

d) dicumyl peroxide, e) $N$-cyclohexyl-2-benzothiazole sulfenamide, f) tetramethylthiuramdisulfide 
吸収で構成されている形状を示した。硫黄架橋の場合，使 用する加硫助剂種の影響により $\mathrm{g}$ 值の異なる数種類の硫黄 ラジカルが発現する ${ }^{5)}$. 現在，スペクトル分解によりこれ らのラジカル種について同定を試みているがまだ結論には 至っていないので定量的解析は出来ていない.

Figure 3 および4のスペクトルからラジカル濃度とひず みの関係を求めその結果をFigure 6 に示した。前述した ように，ひずみ０\%でも試料作製時に発生したラジカルの 存在が認められる.SBR/Sulfur/CBS試料において，ラジ カル濃度はひずみ $100 \%$ \%まで緩やかに増加した後, さらな るひずみの増加にともないラジカル濃度は急激に増大し た。このようなひずみ増加に伴うラジカル濃度の増加は, 我々が以前報告した結果と一致し ${ }^{3,4)}$ ，ひずみによって破 壊された架橋構造およびゴム分子鎖切断で発生したラジカ ルによってもたらされた，と考えられる，すなわち，低ひ ずみ領域では, $\mathrm{C}-\mathrm{S}-\mathrm{C}$ および $\mathrm{C}-\mathrm{S}-\mathrm{S}-\mathrm{C}$ の結合エ ネルギーが $\mathrm{C}-\mathrm{C}$ のそれより低い7）ことが原因で，硫黄を 含む結合部の切断が生じる一方, 高ひずみ領域ではこれに 加え，ゴム分子鎖切断による炭素ラジカル濃度が増加する ためひずみ増加に伴うラジカル濃度増加が顕著になったも のと考えられる. SBR/DCP試料も伸長変形に伴うラジカ ル濃度の増加はひずみ $50 \%$ 付近から認められるようにな る. ラジカル濃度が増加を始めるひずみは, 変形時, ゴム 分子鎖やネットワーク構造に課せられる応力に直接関連 し，架橋密度やその均一性に依存すると考えられる。それ ゆえ，これに関する検討を開始したところである。

\section{2 伸長変形下におけるラジカル濃度の時間依存性}

前述のように架橋ゴムは, 伸長変形によりゴム分子鎖と 架橋構造が部分的に破壊され，その結果としてラジカルが 発生する．発生したラジカルの化学反応性は，ゴム材料の 物性変化に対して重要な役割を担っていると考えられる. そこで，伸長変形で発生したラジカルの反応性について検 討を行った。測定に用いた試料はポリイソプレン過酸化物

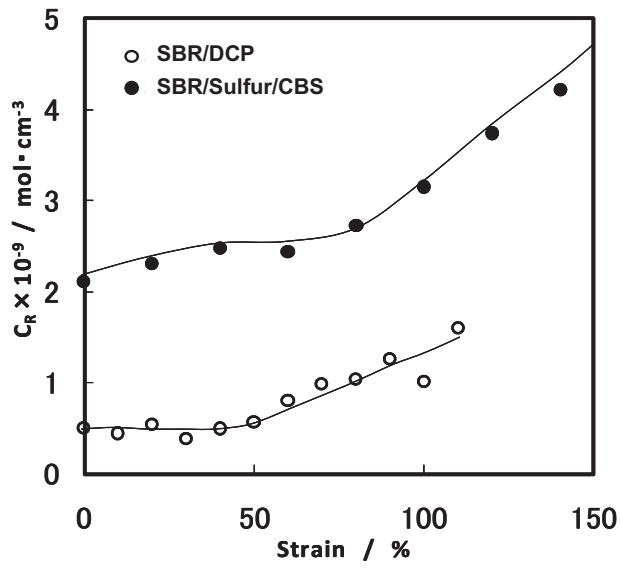

Figure 6 Relation between radical concentration $\left(\mathrm{C}_{\mathrm{R}}\right)$ and strain for vulcanized SBR
架橋（PD）およびポリイソプレン硫黄架橋（PS）の二種 類であり，それらの試料はTable 1 に示した配合表に従っ て作製したものである。

両試料のラジカル濃度は，前節で示した結果同様，ひず み増加とともに増加するが，この増加は測定時間内の平均 值であり，あるひずみで発生したラジカル量から反応によ り消失したラジカル量が差し引かれた結果を示している. 従って，ひずみ増加にともなうラジカル濃度の増加は消失 するラジカル量よりも発生するラジカル量が多いことを示 している，このことは，ひずみ回復過程で，ひずみ回復と ともにとラジカル濃度が減少する事実からも支持される.

Figure $7^{6)}$ は，PDおよびPS 試料を $10 \mathrm{~mm} / \mathrm{min}$ で 200 \%まで伸長後同速度でひずみ $25 \%$ \%で回復させた時点で ひずみを固定し一定時間ごとの ESR 測定から得られたラ ジカル濃度の保持率（25\%ひずみ到達直後のラジカル濃 度を基準）と保持時間との関係を示したものである。ひず み回復過程ではラジカルの発生よりも反応によるラジカル の消失が主体である。また，その反応速度はラジカル種や ラジカル種を取り巻く環境に支配される，と考えられる。 実際，Figure 7 の結果にも示されているように両試料間で 保持率の時間依存性は大きく異なる．PD試料で発生した ラジカルは炭素ラジカルであるのに対し，PS試料で発生 したラジカルは炭素ラジカルのほかに硫黄ラジカルも含ま れている可能性がある。炭素ラジカルはポリエニルラジカ ルのような比較的安定な共鳴構造をとる可能性があり，そ の場合の反応性は低い。一方硫黄ラジカルは構造的に不安 定であり反応性は高い，と考えられる。このような反応性 の違いがFigure 7 で示した結果に反映されているものと 考えられる。このようなラジカル反応は, 伸長変形によっ て部分的に破壊されたネットワーク構造の修復に関与して いる可能性があることから，興味ある結果である。

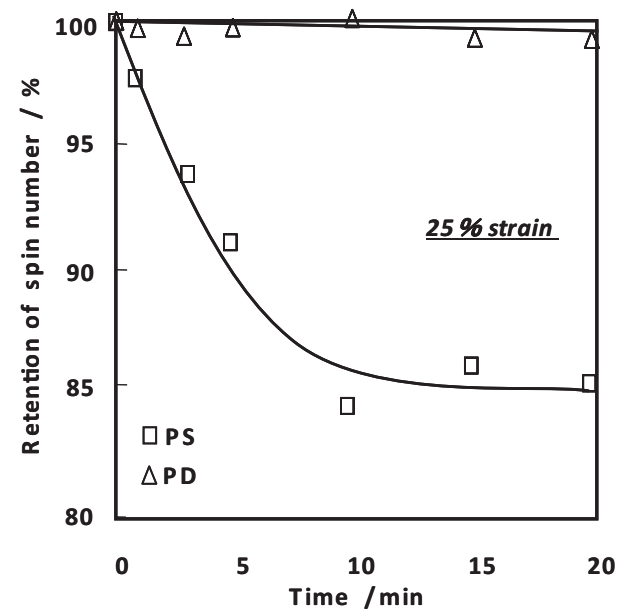

Figure 7 Retention of spin number as a function of time at room temperature for vulcanized IR 


\section{3 伸長変形によるラジカル濃度変化と結晶化挙動と の相関 8$)$}

ある種のジエン系架橋ゴムには伸長変形過程で結晶化挙動 が認められる。最近では高輝度 X線源に引張り試験機を装着 することにより変形過程での結晶化挙動がリアルタイムで得 られるようになり，伸長結晶化機構解明に大きな前進をもた らした．架橋密度が伸長結晶化に与える影響，ゴム分子鎖の 化学構造が伸長結晶化に与える影響などが明らかになり，こ れらにもとづいて伸長過程における結晶化機構が提案されて いる ${ }^{9,10)}$. しかし，提案されている機構には，前述の伸長変 形過程におけるネットワーク構造の部分的崩壊に関する影響 が取り达まれていない。ここでは，この問題を検討する上で 有用と考えられるデー夕を紹介する。

Figure 8は，Table 2に示した配合表にもとづいて作製 した水素化ニトリルゴム（H－NBR），アクリロニトリル ブタジェンゴム（NBR）扔よびSBR架橋試料について， 200 \%ひずみに扔ける応力とそれにより発生したラジカル 量（ $\left.\Delta \mathrm{C}_{\mathrm{R}}\right)$ の関係をプロットしたものである。ここで, $\Delta \mathrm{C}_{\mathrm{R}}$ は200\%ひずみに扔ける実測ラジカル濃度から未延伸 試料のラジカル濃度を差し引いた值である。また，一定ひ ずみにおける応力の違いは, 架橋密度の異なる試料を用い

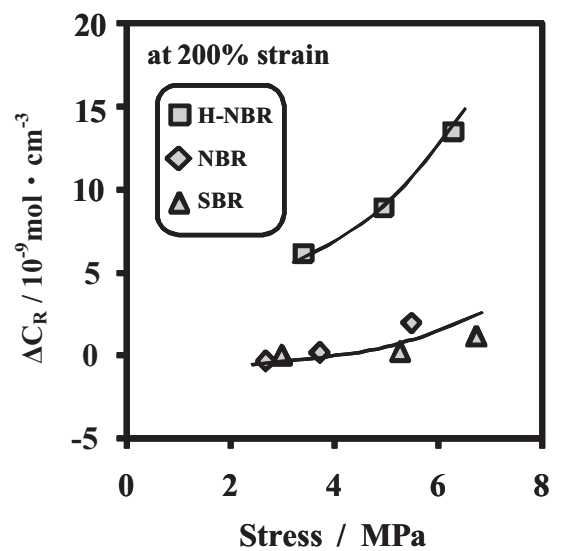

Figure 8 Plot of radical concentration $\left(\Delta C_{R}\right)$ at $200 \%$ strain against stress for various vulcanizates
ることにより得た。

試料に課せられた応力が一定の場合， H - NBR はSBR やNBRに比較してょり多くのラジカルを発生しているこ とがわかる。ここで用いた試料はすべて硫黄/CBSの混合 比を同じとし， かつ同一条件下で加硫したものであり試料 間での架橋形態の違いはほとんどないものと思われる。し たがって化学結合の切断点は, 炭素 - 炭素, 炭素 - 硫黄, 硫黄－硫黄のいずれかであり，架橋形態が類似であるなら ば同一応力における化学結合切断量はほほ等しくなるべき である。しかしながら，H-NBRのみが顕著な化学結合 切断を生じる一因は，H－ NBRに拀けるネットワーク構 造がSBRやNBRに比較して不均一であり，ネットワーク 構造中での応力集中のため構造の一部は破壊されやすいの ではないかと考えられる。ちなみに $\mathrm{H}-\mathrm{NBR}$ は伸長結晶 化挙動を示すが，他の二試料は示さない.

天然ゴム（NR）とポリイソプレン（IR）の基本化学構 造は同じにもかかわらず両者が示す諸物性には違いが認め られる場合が多く，伸長結晶化に扔いてもその程度はNR がIRより顕著であることが知られている。

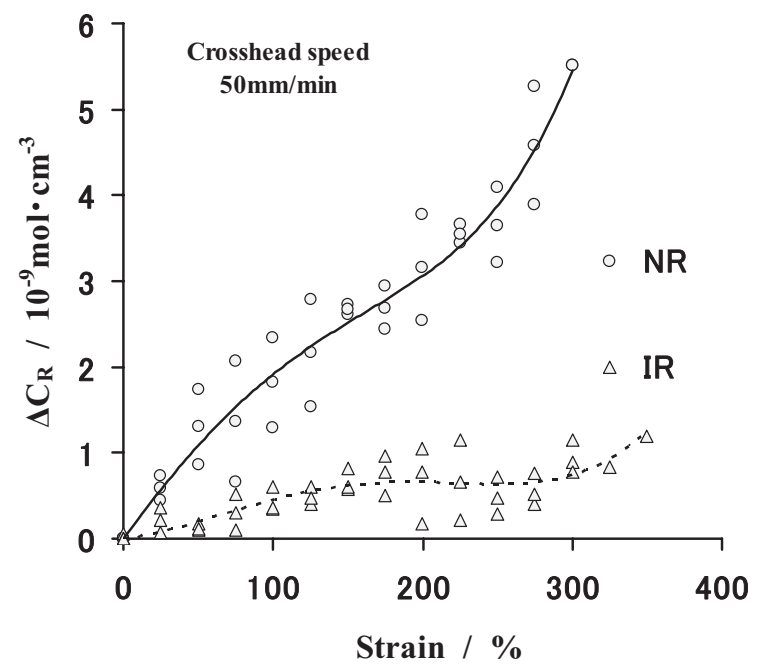

Figure 9 Plot of radical concentration $\left(\Delta C_{R}\right)$ against the strain for IR and NR vulcanizates

Table 2 Formulation of the compounds and crosslink densities

\begin{tabular}{|c|c|c|c|c|c|c|c|c|c|}
\hline \multirow{2}{*}{ Ingredient } & \multicolumn{9}{|c|}{$\mathrm{phr}^{\mathrm{a})}$} \\
\hline & H-NBR1 & H-NBR2 & H-NBR3 & NBR1 & NBR2 & NBR3 & SBR1 & SBR2 & SBR3 \\
\hline H-NBR ${ }^{b)}$ & 100 & 100 & 100 & - & - & - & - & - & - \\
\hline $\mathrm{NBR}^{\mathrm{c}}$ & - & - & - & 100 & 100 & 100 & - & - & - \\
\hline $\mathrm{SBR}^{\mathrm{d})}$ & - & - & - & - & - & - & 100 & 100 & 100 \\
\hline Zinc oxide & 3 & 3 & 3 & 3 & 3 & 3 & 3 & 3 & 3 \\
\hline Stearic acid & 2 & 2 & 2 & 2 & 2 & 2 & 2 & 2 & 2 \\
\hline Sulfur & 1 & 2 & 3 & 1 & 1.5 & 2 & 1 & 1.5 & 2 \\
\hline $\mathrm{CBS}^{\mathrm{e})}$ & 1 & 2 & 3 & 1 & 1.5 & 2 & 1 & 1.5 & 2 \\
\hline$v \mathrm{e} \times 10^{-4} / \mathrm{mol} \cdot \mathrm{cm}^{-3}$ & 3.19 & 3.56 & 3.84 & 2.24 & 2.69 & 3.12 & 2.14 & 2.42 & 2.93 \\
\hline
\end{tabular}

a) weight per hundred rubber, b) hydrogenated nitrile rubber, c) acrylonitrile-butadiene rubber,

d) styrene-butadiene rubber, e) $N$-cyclohexyl-2-benzothiazole sulfenamide 


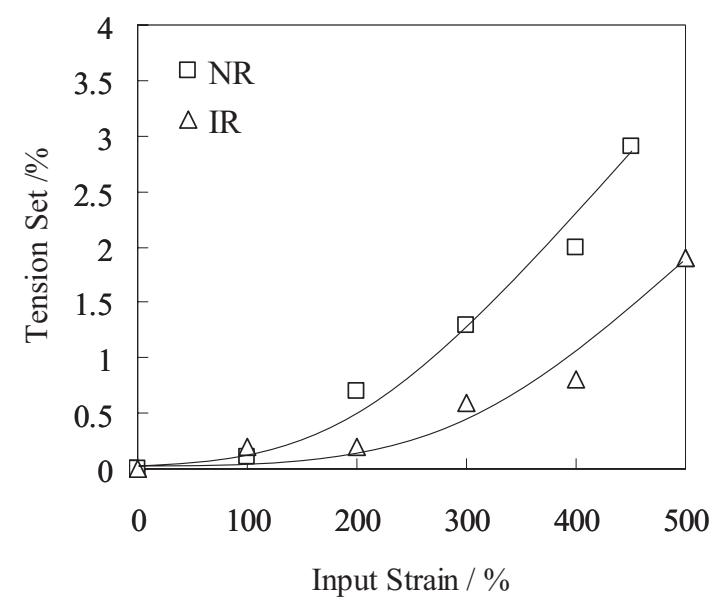

Figure 10 Tension set as a function of initial strain for IR and NR vulcanizates

Figure 9 は，類似の架橋密度と架橋形態を有するNRお よびIR加硫試料について室温における伸長ひずみと発生 ラジカル量 $\left(\Delta \mathrm{C}_{\mathrm{R}}\right)$ との関係を示したものである。ひず み増加に伴い $\Delta \mathrm{C}_{\mathrm{R}}$ は増加するが，その程度は IRより $\mathrm{NR}$ において顕著である。

Figure 10 は, Figure 9 と同一試料について一定ひずみ を課した後の残留ひずみを，課した初期ひずみに対してプ ロットしたものである、いずれのひずみでも NRの残留ひ ずみはIRのそれに比較して大きい. Figure 9 および10の 結果は，前述のネットワーク構造の不均一性にもとづいた 説明を支持するものである。さらに，不均一度が高くネッ トワーク内の応力集中による構造の部分的破壊が顕著な試 料ほど伸長結晶化挙動が顕著であることは，伸長結晶化が ゴム分子鎖の伸長に加えて，伸長方向への並進移動も関与
していることを示唆している.

\section{4. おわりに}

ゴム材料は，厳しい環境下（力学的）で利用される場合 が多いにもかかわらずタフである。しかし，このような環 境下におけるゴム材料の化学的安定性は, 本稿で述べたよ うに決して高くはない。この一見矛盾した事実の一因を説 明してくれるのが伸長変形下での ESR 情報である．この 方法を用いることによりゴム材料の疲労, 劣化に関して定 量的解析が進み, それがゴム材料設計にフィードバックさ れるようになることを期待する。

\section{References}

1 ) Natarajan, R.; Reed, P. E.: J. Polym. Sci. Part A-2, 10, 585 (1972)

2 ) Mead, W. T.; Porter, R. S.; Reed, P. E.: Macromolecules, 11, 56 (1978)

3 ) Suzuki, N.; Ito, M.; Yatsuyanagi, F.: Polymer, 46, 193 (2005)

4 ) Ito, M.; Isago, H.; Suzuki, N.: J. Appl. Polym. Sci., 108, 1385 (2008)

5 ) Funatsu, J.; Ito, M.: Kobunshi Ronbunshu, 65, 369 (2008)

6 ) Takagi, R.; Funatsu, J.; Ito, M.: Nipponn Gomи Kyokaishi, 81, 460 (2008)

7 ) Ossefort, Z. T.: Rubber World, 140, 69 (1959)

8 ) Takagi, R.; Ito, M.: Nippon Gomи Kyokaishi, 83, 311 (2010)

9 ) Toki, S.; Hsiao, B. S.: Macromolecules, 36, 5915 (2003)

10) Tosaka, M.; Murakami, S.; Poompradub, S.; Kohjiya, S.; Ikeda, Y.; Toki, S.; Scis, I.; Hsiao, B. S.: Macromolecules, 37, 3299 (2004)

\section{日本語表記参考文献}

5 ）船津淳司，伊藤眞義 : 高分子論文集，65, 369（2008）

6 ）高木隆一, 船津淳司, 伊藤眞義：日本ゴム協会誌，81，460 (2008)

8 ）高木隆一，伊藤眞義 : 日本ゴム協会誌，83,311（2010） 